\title{
Expression of HSP70 in cerebral ischemia and neuroprotetive action of hypothermia and ketoprofen
}

\author{
Daniela Pretti da Cunha Tirapelli ${ }^{1}$, Carlos Gilberto Carlotti Junior ${ }^{1}$, \\ João Pereira Leite ${ }^{2}$, Luis Fernando Tirapelli', Benedicto Oscar Colli
}

\begin{abstract}
Heat shock proteins (HSPs) are molecular chaperones that bind to other proteins to shepherd them across membranes and direct them to specific locations within a cell. Several injurious stimuli can induce Hsp70 expression, including ischemia. This study aimed to investigate the pattern of expression of protein (immunohistochemistry) and gene (real-time PCR) Hsp70 in experimental focal cerebral ischemia in rats by occlusion of the middle cerebral artery for 1 hour and the role of neuroprotection with hypothermia $(H)$ and ketoprofen $(K)$. The infarct volume was measured using morphometric analysis defined by triphenyl tetrazolium chloride. It was observed increases in the protein $(p=0.0001)$ and gene $(p=0.0001) \mathrm{Hsp} 70$ receptor in the ischemic areas that were reduced by $\mathrm{H}$ (protein and gene: $p<0.05), K$ (protein: $p<0.001)$, and $H+K$ (protein: $p<0.01$ and gene: $p<0.05)$. The $\mathrm{Hsp} 70$ increases in the ischemic area suggests that the Hsp70-mediated neuroexcitotoxicity plays an important role in cell death and that the neuroprotective effect of both, $\mathrm{H}$ and $\mathrm{K}$ are directly involved with the Hsp70.
\end{abstract}

Key words: Hsp70 expression, cerebral ischemia, neuroprotection, hypothermia, ketoprofen.

Expressão de HSP70 na isquemia cerebral e a ação neuroprotetora da hipotermia e do cetoprofeno

\section{RESUMO}

Proteínas de choque térmico (HSPs) são chaperones moleculares que se ligam a outras proteínas para atravessar as membranas e encaminhá-las para locais específicos dentro de uma célula. Vários estímulos nocivos podem induzir a expressão de Hsp70, incluindo isquemia. Este estudo teve como objetivo investigar o padrão de expressão protéica (imunohistoquímica) e gênica (PCR em tempo real) de Hsp70 na isquemia cerebral focal experimental em ratos pela oclusão da artéria cerebral média durante 1 hora e o papel da neuroproteção com hipotermia (H) e cetoprofeno (C). O volume de infarto foi calculado através da análise morfométrica definido por cloreto de trifenil tetrazólio. Foi observado aumento na expressão proteína $(p=0,0001)$ e gênica $(p=0,0001)$ de $\mathrm{Hsp} 70$ nas áreas isquêmicas que foram reduzidas pela $\mathrm{H}$ (proteína e gene: $p<0,05$ ), $C$ (proteína: $p<0,001$ ) e $H+K$ (proteína: $p<0,01$ e gene: $p<0,05)$. $\mathrm{O}$ aumento de $\mathrm{Hsp} 70$ na área isquêmica sugere que a neuroexcitotoxicidade

\section{Correspondence} Daniela Pretti da Cunha Tirapelli Departamento de Cirurgia e Anatomia FMRP/USP - Campus Universitário 14048-900 Ribeirão Preto SP - Brasil E-mail: daniela@rca.fmrp.usp.br

\section{Support}

This study was supported by FAPESP (Fundação de Amparo à Pesquisa do Estado de São Paulo) grant 2005/00381-8

Received 15 September 2009

Received in final form 02 March 2010 Accepted 10 March 2010 mediada pela Hsp70 desempenha um papel importante na morte celular e que o efeito neuroprotetor tanto da $\mathrm{H}$ quanto do $\mathrm{C}$ está diretamente envolvido com a Hsp70. Palavras-chave: expressão de Hsp70, isquemia cerebral, neuroproteção, hipotermia, cetoprofeno.

Focal cerebral ischemia produces changes in gene transcription and translation that are related to the extent of blood flow reduction. While total protein synthesis is generally reduced with ischemia, some genes, including the c-fos immediate ear- 
ly gene and the $70 \mathrm{kD}$ heat shock stress gene Hsp70, are induced with ischemia ${ }^{1-3}$.

The heat shock protein (HSP) family is induced in the brain by several insults including excitotoxin exposure, trauma, elevated body temperature and cerebral ischemia $^{4-7}$. The Hsp70 expression is elevated mainly in the area of ischemic penumbra ${ }^{8-10}$ and delection of the Hsp70 gene exacerbate apoptosis after focal cerebral ischemia in mice ${ }^{11}$. Olsson et al. ${ }^{6}$ suggested that the increased expression of the Hsp70 is an indicator of cellular stress. Recent work has shown that HSP proteins modulate inflammatory response either by potentiating ${ }^{12}$ or inhibiting them ${ }^{13,14}$ and suggest that Hsp70 brain protection against ischemia is done through an anti-inflammatory mechanism.

Several pharmacological procedures have been used in an attempt to reduce the area involved in the ischemic process. Among them, hypothermia ${ }^{15,16}$ and anti-inflammatory drugs ${ }^{17-19}$ and hypothermia in combination with anti-inflammatory drugs $\mathrm{s}^{18}$, has proved to be effective in providing protection after cerebral ischemia. Anti-inflammatory agents are used to attenuate the inflammatory response triggered by the ischemic phenomenon ${ }^{18}$, with emphasis on ketoprofen ${ }^{17,19}$, a non steroid agent with a very potent analgesic and anti-inflammatory action, acting as a possible antagonist of the $\mathrm{N}$-methyl-d-aspartate receptors (NMDARs) ${ }^{20}$. Its neuroprotective effect was attributed by Asanuma et al. ${ }^{17}$ to decrease the antagonism of acetylcholine receptors caused by transient ischemia in gerbils. Experimental studies have also demonstrated the protective action of ketoprofen against ischemia in neurons of the retina and brain tissues in transient focal ischemia ${ }^{21}$.

This study aimed to investigate the pattern of expression of protein and gene Hsp70, in an experimental model of transient focal cerebral ischemia without reperfusion and the possible neuroprotective effect of hypothermia and ketoprofen.

\section{METHOD}

One hundred and twenty adult male rats (Rattus norvegicus) weighing 280-310 g were used and the animals were randomly divided into 3 experimental groups: control (C), 20 animals sacrificed without being submitted to the surgical procedure; sham (S), 20 control animals submitted to complete simulation of the surgical procedure but without obstruction of the middle cerebral artery (MCA) and then sacrificed, and ischemic (I), 80 animals submitted to focal ischemia by occlusion of the MCA for 1 hour and then sacrificed. This group was subdivided into 4 subgroups of 20 animals each: ischemic subgroup (Sg I), ischemic subgroup submitted to hypothermia ( $\mathrm{Sg}$ $\mathrm{IH})$, ischemic subgroup treated with ketoprofen (Sg IK), and ischemic subgroup submitted to hypothermia and treated with ketoprofen (Sg IHK). Ten animals from each experimental group, for a total of 60 animals, were used for the delimitation of the ischemic area using a morphometric method for controlling the efficacy and the extension of the ischemia. The experiments were carried out according to the Ethical Principles for Experimental Animals (COBAO) and the study was approved by the Animal Experimentation Committee (CETEA) of the Faculty of Medicine of Ribeirão Preto, University of São Paulo (Protocol n 0347/2005).

\section{Induction of cerebral ischemia}

All animals were partially anesthetized by halothane inhalation and intubated with an orotracheal cannula. At two times during the ischemic period, arterial blood samples were collected for the determination of glycemia, pa$\mathrm{CO}_{2}, \mathrm{paO}_{2}$ and $\mathrm{pH}$. The animals in the $\mathrm{Sg} \mathrm{IH}$ subgroup were submitted to moderate intra-ischemic hypothermia $\left(32-34^{\circ} \mathrm{C}\right)$ by anesthesia itself and by air conditioning the room, starting 15 minutes before the surgical procedure to induce ischemia. The animals in the Sg IK subgroup received an intravenous injection of ketoprofen at the dose of $10 \mathrm{mg} / \mathrm{kg}$ body weight 15 minutes before the induction of ischemia, and the animals in the Sg IHK subgroup were submitted to intra-ischemic hypothermia and similarly injected with ketoprofen. MCA occlusion was carried out through the external carotid artery which was ligated cranially and sectioned for the retrograde introduction of a $2.5 \mathrm{~cm}$ long obstructive 4-0 mononylon suture with one end thickened with silicone over an extension of $5 \mathrm{~mm}^{22}$. The suture was introduced until to reach the common carotid artery and then cranially progressed through the internal carotid artery until to reach and to obstruct the MCA.

\section{Morphometric analysis of infarct volume}

Infarct volumes were measured by morphometric analysis of infarct areas that were defined by 2,3,5-triphenyl tetrazolium (TTC). The brains of the animals were removed and cut into coronal sections using a rat brain matrice and were placed in a $2 \%$ solution of the dye TTC, developed at $37^{\circ} \mathrm{C}$ for 30 minutes, and then stored in $10 \%$ buffered formalin solution. Cross-sectional area of the TTC-stained region for each brain slice was determined using an image analyzer (Axion vision 4.6 - Carl Zeiss). After integration of these stained areas, the indirect method of Swanson et al. ${ }^{23}$ was used to determine infarct volume (subtraction of residual left hemisphere cortical volume from the cortical volume of the intact right hemisphere).

\section{Analysis of protein expression by immunohistochemistry}

The samples were embedded in paraffin and coronal sections $(3 \mu \mathrm{m})$ of the brain were incubated with $3 \% \mathrm{H}_{2} \mathrm{O}_{2}$ 
and Pierce solution to block endogenous peroxidase and biotin, respectively. Sections were subsequently incubated with primary antibody against Hsp70 (1:200 dilution - CHEM - AB9864 - Chemicon ${ }^{\circ}$ ) and with biotin-conjugated secondary anti-rabbit antibody (1:1000; Vector Laboratories Inc., Burlingame, CA) and streptavidin-conjugated peroxidase (Vecstatin Abc kit, Vector Laboratories Inc.). Color was developed by the addition of DAB (Sigma Chemical, St. Louis, MO). To evaluate the background reaction, procedures were also performed in sections incubated only with the secondary antibodies (indirect technique) or in the absence antibodies (direct technique). For the analysis of protein expression of $\mathrm{Hsp} 70 \mathrm{a}$ field in an increase of $400 \times$ in the area where there was greater concentration of positive cells or marked (areas of "hot spots") was selected in each layer of immunohistochemical reaction. The number with positive staining for Hsp70 was measured by using a camera (Axio Cam, Zeiss, Germany) and the software Axiovision 4.6 (Zeiss, Germany).

The method used for counting the cells positive to antibody study was to quantify "in crosses" of cytoplasmic immunoreactivity of cells of nervous tissue. The fields chosen in the slides were evaluated as the percentage of cells marked and graded from 0 (zero): no mark, up to 25\%: $1+$ (low expression), $25 \%$ to 50\%: $2++$ (intermediate expression); $50 \%$ to $75 \%: 3+++$ (high expression) and over $75 \%$ of cells marked: $4++++$ (high expression).

\section{RNA extraction and CDNA synthesis}

After removal of the brain, the cortex of the left cerebral hemisphere was isolated and a sample measuring $7 \mathrm{~mm}$ in diameter, was obtained by biopsy from the central ischemic region, corresponding to the irrigation zone of the MCA. The samples were placed in cryotubes and stored in liquid nitrogen at $-196^{\circ} \mathrm{C}$ until the time for RNA extraction. For this procedure, $250 \mu \mathrm{l}$ PBS $+750 \mu \mathrm{l}$ TRIZOL were added to the brain tissue samples which were then lysed in a Polytron homogenizer for about 3 minutes. Next, total RNA was extracted by the TRIZOL method (Invitrogen, Carlsbad, CA, USA) according to manufacturer instructions. Complementary DNA (cDNA) was constructed by reverse transcription using the enzyme Superscript II and the DNA obtained was amplified by real-time quantitative PCR (RQ-PCR).

\section{Analysis of gene expression patterns by RQ-PCR}

For the quantitative analysis of the gene under study, Hsp70 (Rn 01525984), we used the commercially available system TaqMan Assay-on-demand, which consists of oligonucleotides and probes (Applied Biosystems, Foster City, CA, USA). Reverse transcription was performed using $4 \mu \mathrm{g}$ total RNA for each sample in $40 \mu \mathrm{L}$ of the total reaction mixture, with the addition of oligo $(\mathrm{dT})_{20}$ (Cat. No. 18418-020, Invitrogen) and Superscript II reverse transcriptase (Cat. No. 18064-022, Invitrogen), according to manufacturer instructions. The cDNA obtained was diluted 1:10 and $2.5 \mu \mathrm{L}$ was used for each $15 \mu \mathrm{L}$ of the RQ-PCR mixture using the TaqMan Master Mix (Applied Biosystems).

All reactions were carried out in duplicate and analyzed with the 7500 Sequence Detection System apparatus (Applied Biosystems). Data were analyzed using the ABI-7500 SDS software. The maximum standard deviation between duplicates was $10 \%$. The total RNA absorbed was normalized on the basis of the $\mathrm{Ct}$ value for the GAPDH gene (Rn_99999916). The variation of expression among samples was calculated by the $2^{-\Delta \Delta \mathrm{Ct}}$ method, with the mean delta $\mathrm{Ct}$ value for a group of 20 samples from control rats being used as a calibrator.

\section{Statistical analysis}

The expression of the gene and protein under study showed normal distribution in the various groups. Data concerning the mean gene and protein expression in the various groups were analyzed statistically by one-way ANOVA followed by the Bonferroni post-test using the GraphPad Prism software, version 4.00 for Windows, (GraphPad Software, San Diego, CA, USA). The level of significance was set at $\mathrm{p}<0.05$ for two-tailed tests.

\section{RESULTS}

Rats subjected to a 60 minutes period by occlusion of the MCA showed after morphometric analysis that the infarct area corresponding to the territory of irrigation of the MCA was clearly observed in the animals of the ischemic group.

The analysis of the percentage of the volume of ischemic area in relation to the normal hemisphere among the animals of the ischemic group (SgIH, SgIK and SgI$\mathrm{HK})$ revealed a smaller area of infarction in relation to animals of the ischemic subgroup ( $\mathrm{SgI})(\mathrm{p}<0.0001$, one-way ANOVA, $\mathrm{p}=0001$, Bonferroni post-test, and similar areas to that observed in animals of the control group.

The analysis of protein expression of $\mathrm{Hsp} 70$ by immunohistochemistry (Fig 1) showed that it was intermediate $(++)$ for all animals in subgroups SgI, SgIH and SgIHK, and that average percentage of positive cells were $40.96 \%$; $36.73 \%$ and $36.20 \%$, respectively. The expression was also intermediate $(++)$ for all animals of the subgroup SgIK, with low intensity $(+)$ only in animal 2 and with the average percentage of positive cells of $28.61 \%$.

Fig 2 shows mean and standard deviation of the percentage of positive cells to Hsp70 antibody in the ischemic group. There was a statistically significant difference $(\mathrm{p}=0.0001$ one-way ANOVA) between the subgroups 


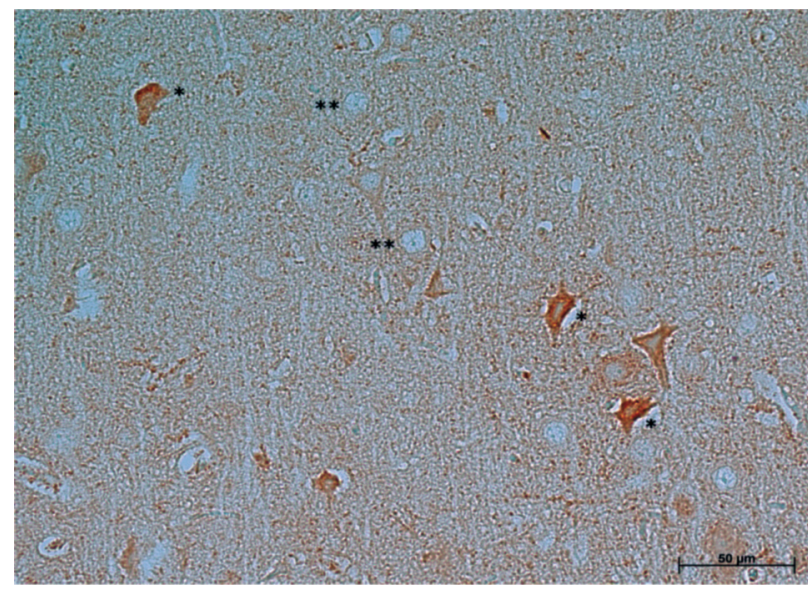

Fig 1. Photomicrography of the expression of Hsp70 antibody in the SgIHK subgroup. Positive cells $\left(^{*}\right)$ and negative cells $\left(^{(*}\right)$ in the nervous tissue to the antibody $(400 \times)$.

SgIxSgIH $(\mathrm{p}<0.05), \operatorname{SgIxSgIK}(\mathrm{p}<0.001)$, SgIxSgIHK $(\mathrm{p}<0.01)$, Bonferroni post test.

Fig 3 illustrates the mean expression of the Hsp70 gene in the experimental groups. The expression in the animals of the ischemic group was higher when compared with control and sham ( $\mathrm{p}=0.0001$, one-way ANOVA, $p<0.05$, Bonferroni post-test), and it was lower in the animals of the subgroups SgIH and SgIHK compared to control, sham and ischemic (SgI) animals ( $\mathrm{p}=0.0001$, oneway ANOVA, $\mathrm{p}<0.05$, Bonferroni post-test).

\section{DISCUSSION}

Cerebral ischemia is one of the devastating neuropathological disorders known to humans. Though several putative molecules have been investigated for pharmacological intervention for preventing or reducing cerebral ischemia, no successful therapy has been achieved ${ }^{24}$.

The model of ischemia induction by occlusion of the MCA with an obstructive suture has been used by several investigators and has been shown to produce constant and reproducible focal injuries ${ }^{19,22}$. In our study, morphological measure of the infarct volume was randomly performed in 10 animals of each experimental group for controlling the occurrence of ischemia. All animals submitted to ischemia showed some evidence of infarct in the ischemic hemisphere. The sham group, consisting of animals subjected to complete simulation of the surgical procedure, but without obstruction of the MCA, was used in order to demonstrate that the surgical procedure that these animals are subjected to the access to the MCA does not affect the results obtained and therefore different from control animals, which does not undergo any procedure before the sacrifice.

Modulation of inflammatory response by $\mathrm{Hsp70}$ is controversial: some suggest potentialization by this pro-

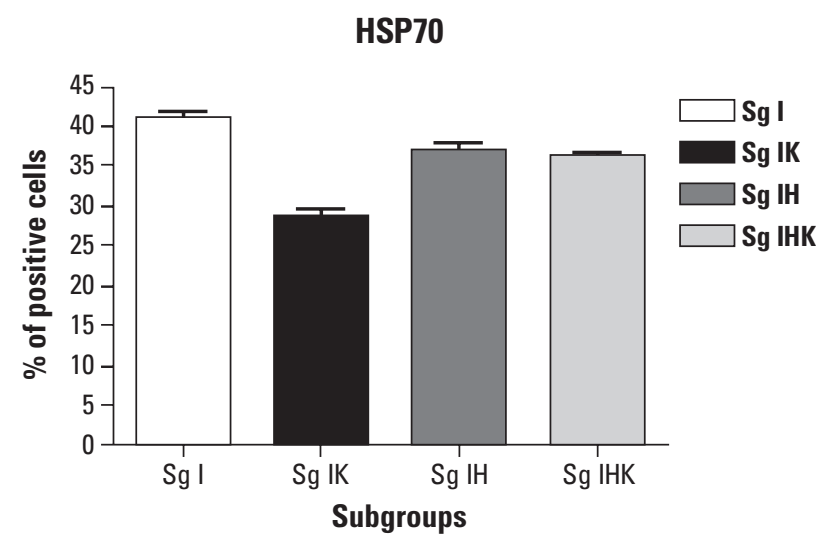

$\mathrm{Sg}$ I: ischemic subgroup; $\mathrm{Sg}$ IK: ischemic+ketoprofen subgroup; $\mathrm{Sg} \mathrm{IH}$ : ischemic+hypothermia subgroup; $\mathrm{Sg} \mathrm{IHK}$ : ischemic+hypothermia+ ketoprofen subgroup.

Fig 2. Mean and standard deviation of the percentage of positive cells to Hsp70antibody in the ischemic group.

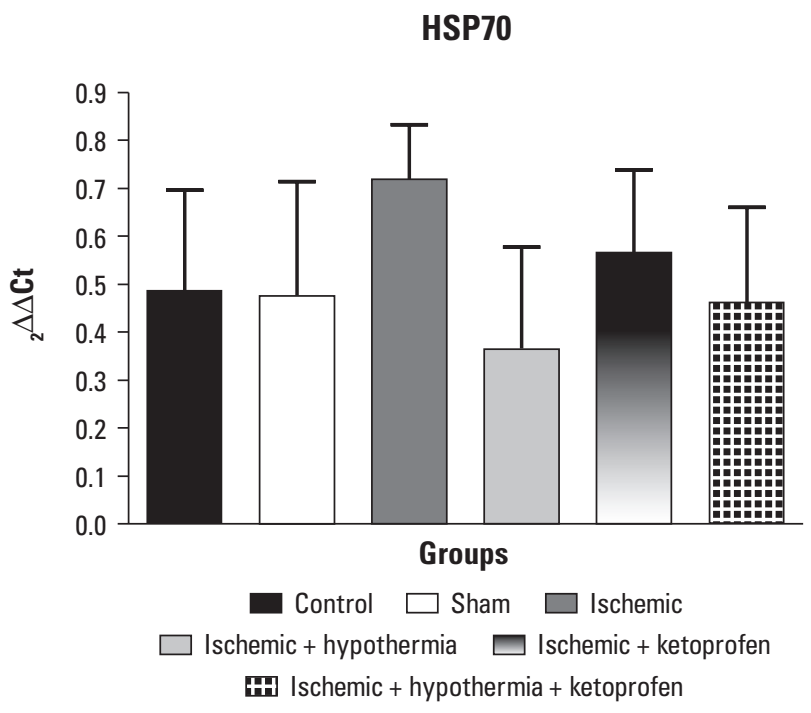

Fig 3. Gene expression of the Hsp70 gene in the groups studied. Data are reported as means \pm SD. The deviation bars indicate a 95\% confidence interval.

tein $^{12}$ and others inhibition ${ }^{13,14}$. Zheng et al. ${ }^{14}$, suggest that overexpression of Hsp70 not only protect brain against ischemia but also appear to do via an anti-inflammatory mechanism.

As several pathways leading to cell death are activated after an ischemic insult, effective neuroprotection might require a combination of drugs that target distinct pathways during the evolution of ischemic injury. This has led to a number of papers studying combinations of pharmacological agent $\mathrm{s}^{25-27}$ and multiple mechanisms for hypothermiainduced neuroprotection have already been identified ${ }^{28-30}$.

Using a global model of cerebral ischemia in mice, Olsson et al. ${ }^{6}$ noted a change in Hsp70 expression in the 
CA1-CA3 regions of the hippocampus. When coupled with hypothermia $\left(33^{\circ} \mathrm{C}\right)$ there was a decrease in the expression of Hsp70 and consequent decrease in cellular damage. The authors suggest that increased expression of Hsp70 in cerebral ischemia is an indicator of cellular stress. Our results corroborated the data of literature that decrease of Hsp70 lead to an neuroprotector effect and this effect also was observed when this protein with hypothermia and ketoprofen alone as ketoprofen plus hypothermia. More studies with this drug are necessary for better understanding participation of the Hsp70 in the inflammatory response and especially its actions as anti-inflammatory agent in ischemic brain.

In conclusion, the increased expression in the HSP70 after experimental ischemia suggests its involvement with cerebral ischemia. The neuroprotective agents associated with ischemia evaluated in this study (hypothermia, ketoprofen and hypothermia+ketoprofen) proved to be effective. This was suggested by the reduction of both gene and protein expression of HSP70. The association between hypothermia+ketoprofen do not proved to be more effective then the isolated action of these two neuroprotective agents.

\section{REFERENCES}

1. Kinouchi H, Sharp FR, Hill MP, Koistinaho J, Sagar SM, Chan PH. Induction of 70-kDa heat shock protein and hsp70 mRNA following transient focal cerebral ischemia in the rat. J Cereb Blood Flow Metab 1993;13:105-115.

2. Kinouchi H, Sharp FR, Chan PH, Koistinaho J, Sagar SM, Yoshimoto T. Induction of c-fos, junB, c-jun, and hsp70 mRNA in cortex, thalamus, basal ganglia, and hippocampus following middle cerebral artery occlusion, J Cereb Blood Flow Metab 1994;14:808-817

3. Li Y, Chopp M, Zhang ZG, Zhang RL, Garcia JH. Neuronal survival is associated with 72-kDa heat shock protein expression after transient middle cerebral artery occlusion in the rat. J Neurol Sci 1993;120:187-194.

4. Ren $M$, Leng $Y$, Jeong $M$, Leeds PR, Chuang DM. Valproic acid reduces brain damage induced by transient focal cerebral ischemia in rats: potential roles of histone deacetylase inhibition and heat shock protein induction. J Neurochem 2004;1358-1367.

5. Giffard RG, Yenari MA. Many mechanisms for hsp70 protection from cerebral ischemia. J Neurosurg Anesthesiol 2004;16:53-61.

6. Olsson T, Hansson O, Nylandsted J, Jäättelä M, Smith ML, Wieloch T. Lack of neuroprotection by heat shock protein 70 overexpression in a mouse model of global cerebral ischemia. Exp Brain Res 2004;154:442-449.

7. Himeda T, Tounai H, Hayakawa N, Araki T. Postischemic alterations of BDNF, NGF, HSP 70 and ubiquitin immunoreactivity in the gerbil hippocampus: pharmacological approach. Cell Mol Neurobiol 2007;27:229-250.

8. Sharp FR, Massa SM, Swanson RA, et al. Heat-shock protein protection. Trends Neurosci 1999:22:97-99.

9. Snider BJ, Du C, Wei L, Choi DW. Cycloheximide reduces infarct volume when administered up to 6 h after mild focal ischemia in rats. Brain Res 2001:917: 147-157.
10. Schmidt-Kastner R, Zhang B, Belayev L, et al. DNA microarray analysis of cortical gene expression during early recirculation after focal brain ischemia in rat. Brain Res Mol Brain Res 2002;108:81-93.

11. Lee KJ, Terada K, Oyadomari S, Inomata Y, Mori M, Gotoh T. Induction of molecular chaperones in carbon tetrachloride-treated rat liver: implications in protection against liver damage. Cell Stress Chaperones 2004;9:58-68.

12. Svenson PA, Asea A, Englund MC, et al. Major role of HSP70 as a paracrine induce of cytokine prodution in human oxidized LDL tratament macrophages. Atherosclerosis 2006;185:32-38.

13. Malago JJ, Koninkx JF, Tooten PC, van Liere EA, van Dijk JE. Anti-inflammatory properties of heat shock protein 70 and butyrate on Salmonella-induced interleukin-8 secretion in enterocyte-like Caco-2 cells. Clin Exp Immunol 2005;141:62-71.

14. Zheng Z. Anti-inflammatory effects of the $70 \mathrm{kDa}$ heat shock protein in experimental stroke. J Cereb Blood Flow Metab 2008;28:53-63.

15. Baker CJ, Fiore AJ, Frazzini VI, Choudhri TF, Zubay GP, Solomon RA. Intraischemic hypothermia decreases the release of glutamate in the cores of permanent focal cerebral infarcts. Neurosurgery 1995;36:994-1001.

16. Li H. Sex differences in cell death. Ann Neurol 2005;58:317-321.

17. Asanuma M, Asanuma SN, Gómez-Vargas M, Yamamoto M, Ogawa N. Ketoprofen, a non-steroidal anti-inflammatory drug prevents the late-onset reduction of muscarinic receptors in gerbil hippocampus after transient forebrain ischemia. Neurosci Lett 1997;225:109-112

18. Dietrich WD, Busto R, Bethea JR. Postischemic hypothermia and IL-10 treatment provide long-lasting neuroprotection of CA1 hippocampus following transient global ischemia in rats. Exp Neurol 1999;158:444-450.

19. Dias LA, Colli BO, Coutinho Netto J, Lachat JJ. [Focal cerebral ischaemia induced by middle cerebral artery occlusion and the neuroprotective effect of ketoprofen in rats]. Arq Neuropsiquiatr 2000;58:1047-1054

20. McCormack K. Non-steroidal anti-inflammatory drugs and spinal nociceptive processing. Pain 1994;59:9-43.

21. Silva MN, Colli BO, Coimbra NC, Coutinho Netto J. Evaluation of the neuroprotective effect of ketoprofen on rats submitted to permanent focal brain ischemia. Arq Neuropsiquiatr 2007;65:978-984.

22. Carlotti CG Jr, Colli BO, Kazuo JY. [Evaluation of brain ischemia by mitochondrial respiration: experimental model]. Arq Neuropsiquiatr 2001;59:365-371.

23. Swanson RA, Morton MT, Tsao-Wu G, Savalos RA, Davidson C, Sharp FR. A semiautomated method for measuring brain infarct volume. J Cereb Blood Flow Metab 1990;10:290-293.

24. Chaitanya GV, Babu PP. Multiple apoptogenic proteins are involved in the nuclear translocation of apoptosis inducing factor during transient focal cerebral ischemia in rat. Brain Res 2008;1246:178-190.

25. Ma J, Endres M, Moskowitz MA. Synergistic effects of caspase inhibitors and MK-801 in brain injury after transient focal cerebral ischaemia in mice. $\mathrm{Br} J$ Pharmacol 1998;124:756-762.

26. Schulz JB, Weller M, Matthews RT et al. Extended therapeutic window for caspase inhibition and synergy with MK-801 in the treatment of cerebral histotoxic hypoxia. Cell Death Differ 1998;5:847-857.

27. Spinnewyn B, Cornet S, Auguet M, Chabrier PE. Synergistic protective effects of antioxidant and nitric oxide synthase inhibitor in transient focal ischaemia. J Cereb Blood Flow Metab 1999;19:139-143.

28. Busto R, Globus MY, Dietrich WD, Martinez E, Valdes I, Ginsberg MD. Effect of mild hypothermia on ischaemia-induced release of neurotransmitters and free fatty acids in rat brain. Stroke 1989;20: 904-910.

29. Nakashima K, Todd MM. Effects of hypothermia on the rate of excitatory amino acid release after ischaemic depolarization. Stroke 1996;27:913-918.

30. Hachimi-Idrissi S, Van Hemelrijck A, Michotte A. Postischemic mild hypothermia reduces neurotransmitter release and astroglial cell proliferation during reperfusion after asphyxial cardiac arrest in rats. Brain Res 2004;1019:217-225. 